\title{
An Empirical Study of the Method Effect in Analysing the Adoption of IFRS
}

\author{
Christopher von Koch $^{1}$, Ola Nilsson ${ }^{1}$, Micael Jönsson ${ }^{1} \&$ Andreas Jansson ${ }^{1}$ \\ ${ }^{1}$ Linneaus University, School of Business and Economics, Sweden \\ Correspondence: Ola Nilsson, Linneaus University, School of Business and Economics, Sweden. E-mail: \\ ola.nilsson@lnu.se \\ Received: April 2, 2014 \\ Accepted: May 8, 2014 \\ Online Published: May 13, 2014 \\ doi:10.5430/afr.v3n2p153 \\ URL: http://dx.doi.org/10.5430/afr.v3n2p153
}

\begin{abstract}
This study investigates the consequences of using different methods when making conclusions about the effect of IFRS. The study's contribution is related to the suggestion that research design must be considered when analysing the results of prior studies on the adoption of IFRS. In summary, our results demonstrate that the impact of IFRS on accounting quality measured as financial analysts' information environment depends on the model used. Using the same model as in prior research (the BKLS model) our results confirm earlier studies that IFRS adoption improves the information environment for analysts. However, when using a more sophisticated model no such improvement can be found.
\end{abstract}

Keywords: IFRS, Information environment, Analyst forecasts, Comparative study

\section{Introduction}

This study investigates the consequences of using different methods when assessing the effect of IFRS. The paper is a contribution related to the suggestion of Brüggemann, Hitz and Sellhorn (2013) that research design must be considered when analysing the results of prior studies on the adoption of IFRS. Brüggemann et al. (2013) review the vast literature on both the intended and unintended economic consequences of mandatory adoption of IFRS and discuss the large discrepancy in conclusions. According to the authors, the variability in results among prior studies makes it difficult to assess the validity of more general claims about the effects of IFRS, even though individual studies or groups of studies examining the same research question using similar methods may produce evidence supporting seemingly certain claims. The authors therefore claim that there is a problematic mismatch within the research on the effects of IFRS. Beyond this, they also show that there is high uncertainty about whether the adoption of IFRS supports the basic regulatory objectives or not, i.e., the question of whether the adoption of IFRS gives the assumed effect, i.e. higher quality information to the capital markets with resulting improved information environment, is still uncertain even though it is generally assumed that it does.

Brüggemann et al. (2013) concentrate on three types of effects derived from the main foci of the prior literature: financial reporting effects, capital markets effects and macroeconomic effects. The first category reflects the immediate impact of adopting IFRS in regard to properties of financial statements. The two latter categories relate to user responses to adopting IFRS. Brüggemann et al. (2013) show that the empirical research on the intended consequences generally fails to document an increase in the comparability or transparency of financial statements. At the same time, there is an almost unanimous support for a positive effect on capital markets in general, and the same holds on the macroeconomic level; in other words, the positive effect is independent of, for example, the institutional context and/or the specific country. For example, the results of studies focusing on compliance and accounting choice show that there is a great cross-country variation in the reports and that these variations persist for several years after mandatory IFRS adoption (see Kvaal \& Nobes, 2010; 2012). In some countries there is high level of compliance, and in others there is a low level of compliance. Accordingly, this fact contradicts the possibility of from an international perspective making a general claim of a positive effect at the macro level or even for capital markets. Thus, the mismatch raised by Brüggemann et al. (2013) can also be considered an empirical fact.

There are two important arguments that Brüggemann et al. (2013) make based on the perceived mismatch, which is the basis of their call for future research. First, the authors claim that one main reason for the mismatch pertains to research design. For example, the method that is the basis for analysis seems to have an important impact. Second, the present research mostly focuses on intended consequences. The authors claim that the unintended consequences 
need more attention and that analyses should consider both types of consequences. This is, of course, also a matter of how and what is measured, i.e., the method used.

To answer this call, in this study, we use a two-step development of a model designed to measure both a company's public and private information available to financial analysts. The earlier version of the model developed by Barron, Kim, Lim and Stevens (1998) has been used in prior IFRS studies with results showing almost unanimously support for a positive effect of the adoption of IFRS (BKLS model hereafter). The BKLS measure, based on analyst forecasts, has also been used extensively in a variety of other settings (see Barron, Byard, Kile \& Riedl, 2002; Liang, 2003; Botosan \& Stanford, 2005; Doukas, Kim \& Pantzalis, 2006; Yeung, 2009). The later version of the model Sheng and Thevenot (2012), has not, to our knowledge, been used in this type of study (ST model hereafter). Both of these models are based on financial analysts' data and measure the analyst information environment with focus on the uncertainty present in the market, which in turn is used as a proxy for accounting quality. The main difference between the two models is that the BKLS model calculates the uncertainty among analysts at the time when the actual result is released (an ex post measure of uncertainty) while the ST model uses only data known to the analyst when they make the forecast (before the result is released - an ex ante measure of uncertainty). The BKLS model could therefore be criticized for being a proxy for ex ante uncertainty at the time the forecast are made. Since uncertainty is fundamentally an ex ante concept attached to a forecast before the actual earnings are known, it must be constructed using data available in real time. The ST model is therefore developed to give a more realistic measure of both public and private information and therefore analysing the adoption of IFRS better than BKLS. The possibility of obtaining information about the level of public and private information gives us the ability to analyse the combined intended and unintended consequences of the adoption of IFRS. Using both of these models on the same dataset allows us to analyse the consequences of small changes in methods.

Applying the BKLS model shows that IFRS adoption improves public information and total information. This supports earlier study results using the same model (Kim \& Shi, 2012; Beuselinck, Joos, Khurana, \& Van der Meulen, 2010; Byard, Li \& Yu, 2011; Yang, 2011), but contrasts with studies focusing on compliance and accounting choice that generally fails to document a positive effect (Kvaal \& Nobes, 2010; 2012). When using the more developed ST model, we are unable to find this positive effect. Accordingly, this shows that there exists a model effect. This support the suggestion of Brüggemann et al. (2013) that the research design could be an explanation for the inconsistency in prior research conclusions about the impact of IFRS adoption. Our results from the ST model question the claim of an overall positive effect of IFRS on the capital markets and thus there is no mismatch between our results from the ST model and studies focusing on compliance and accounting choice. Therefore, this study suggests that the mismatch that Brüggemann et al. (2013) document may depend on research design.

We make several contributions to the existing literature. First, investors and accounting researchers have long been concerned with the quality of the information environment faced by market participants. Our study questions earlier results that IFRS adoption improves the overall information environment faced by an important group of information users, financial analysts. Second, using the ST model for the first time in studying the effect of IFRS adoption, we add a developed analysis to the already vast literature on this matter. Third, by comparing the results between the BKLS model and ST model we can create awareness about the method effect as well as a possible explanation for the empirical inconsistency in the results within the IFRS research. Fourth, the study gives substance to the question of whether international accounting standards meet the regulatory objectives, which are highly important for future decisions regarding the regulation of the capital market.

\section{The rationale of using financial analyst performance as a measure of accounting quality and information environment}

The vast previous research on the impact of IFRS has typically used timely loss recognition, earnings management and value relevance as indicators of accounting quality (cf. Barth, Landsman \& Lang, 2008), although metrics such as quality indices and appropriateness also appear. All of these metrics fail to directly capture the usefulness of the information for accounting users. Thus, another research stream has used the performance of financial analysts to evaluate IFRS.

Analysts' forecasts are commonly used in the accounting literature to study market participants' expectations. Revsine, Collins and Johnson (2004) and Schipper (1991) argue that analysts are considered to one of the most important and influential users of accounting reports and among the most important information intermediaries between investors and firms. Considering their information-processing ability and access to resources, financial analysts are typically regarded as sophisticated users of accounting information and as being less likely (than naïve investors) to misunderstand the implications of such information (e.g., Schipper, 1991). 
Evidence proposes that analysts rely extensively on accounting information to make forecasts (Block, 1999; Roger \& Grant, 1997). Therefore, if analysts receive access to higher quality accounting reports, they should be able to make better forecasts. Researchers are especially interested in estimating forecast accuracy and uncertainty about future earnings, which have of course been used to evaluate IFRS impact on accounting quality. Because uncertainty is unobservable, evaluating its estimates poses challenging methodological problems. As a result, researchers have experimented with alternative proxies for earnings forecast uncertainty. Forecast dispersion (measured as the standard deviation in analysts' forecasts), which is an indication of the extent of analysts' disagreement regarding a firm's upcoming earnings, can be used as a proxy for investor uncertainty prior to the release of key information (Ramnath, Rock \& Shane, 2008). According to Krishnaswami and Subramaniam (1999), this dispersion is a measure of information asymmetry. They claim that when information asymmetry between a firm and its market is high, it is difficult for the market to evaluate or predict the firm's performance. For example, Byard et al. (2011) found that forecast dispersion and forecast errors decrease but only in countries with both strong enforcement regimes and domestic accounting standards that differ significantly from IFRS. Similar conclusions are suggested in Horton, Serafeim and Serafeim (2013) and Preiato, Brown and Tarca (2013) who demonstrate that IFRS can have a positive impact on forecast accuracy if enforcement is strong.

Consistent with this notion, Tan, Wang and Welker (2011) demonstrate that the accuracy of foreign financial analysts' forecasts increases when IFRS are implemented, particularly if the difference between previous local Generally Accepted Accounting Principles (GAAP) and IFRS is significant. However, domestic analysts' accuracy is not affected by IFRS. Glaum, Baetge, Grothe and Oberdorster (2013), who examined the impact of IFRS on analysts following German firms, separated the effect between improved disclosure and other changes in the firms' information environments. They found that improved disclosure had a modest and positive effect on analysts' accuracy, but they suggest that improvements in the quality of earnings, improvements in firms' investor relations and changes in analyst behaviour have contributed more to the improvement of analyst accuracy.

\subsection{The BKLS model and the ST model}

As seen above, forecast dispersion among analysts is one of the most commonly used measures of earnings forecast uncertainty (see for example, Clement, Frankel, \& Miller, 2003; Yeung, 2009). Dispersion, as a proxy for uncertainty, has several advantages. It is easy to calculate and gives a measure of uncertainty around the time the forecast is made, i.e., in real time. However, Abarbanell, Lanen and Verrecchia (1995) and Johnson (2004), among others, note that this measure does not capture uncertainty to a full extent. Indeed, dispersion represents only one element of uncertainty, namely uncertainty arising from analysts' private information and the diversity of forecasting models. As a result, dispersion tends to be a noisy and unreliable proxy for earnings forecast uncertainty when the uncertainty shared by all analysts becomes dominant or when the change in uncertainty is the construct of interest. The solving of this deficiency could be said to be the basis for the development of the BKLS model proposed by Barron, Kim, Lim and Stevens (1998). According to this model, uncertainty can be estimated as the sum of dispersion and the squared error in the mean forecast. It recognises the fact that uncertainty is composed of two components, public and private information and that the quality of these components can be measured. Note that we use common information as a synonym for public information in this study, as previous studies also have done.

The logic behind the BKLS model's way of measuring the quality is that forecast dispersion and the error in the mean forecast are functions of the quality of public information, the quality of private information, and the number of analysts. By reversing these functions it is possible to infer public and private information quality dispersion, error in the mean forecast, and the number of forecasts and this will make it possible to assess the quality of public and private information by the following equations:

$h=$ the quality (precision) of public information

$$
h=\frac{\mathrm{SE}-\frac{\mathrm{D}}{\mathrm{N}}}{\left[\left(1-\frac{1}{\mathrm{~N}}\right) \mathrm{D}+\mathrm{SE}\right]^{2}}, \quad s=\frac{\mathrm{D}}{\left[\left(1-\frac{1}{\mathrm{~N}}\right) \mathrm{D}+\mathrm{SE}\right]^{2}},
$$

$s=$ the quality (precision) of private information

$S E=$ the expected squared error in the mean forecast

$D=$ the expected sample variance (or dispersion) in forecasts

$N=$ the number of forecasts

In the models, the quality of common (public) information is denoted by $h$ and the quality of the private information is denoted by $s$. There is also an opportunity to measure the quality of total information, $k$, by these two equations. 
Measuring the quality of this information is performed by summarising $h$ and $s$. Additionally, there is a possibility of measuring the relative use of private information $p$ by dividing $h$ with $h+s$. BKLS suggests that one can use observed dispersion and mean squared error as proxies for D and SE to empirically estimate the constructs in equations. Because it is based on information available to analysts at the time the forecasts are made, observed forecast dispersion seems to be a good proxy for its expected counterpart, D. However, using actual earnings to estimate SE, i.e. the expected mean squared error, may pose a serious problem because forecast errors are known to analysts only after the announcement of actual earnings.

Lately there have therefore been claims that using the BKLS measure as a proxy for ex ante uncertainty is problematic. According to Sheng and Thevenot (2012), the BKLS measure only provides an estimate of ex post uncertainty because forecast errors are known to respondents only after the announcement of actual earnings. Sheng and Thevenot (2012) also criticise the BKLS model for being excessively affected by significant unanticipated events following the forecast and for that it relies on the assumption that actual earnings are exogenous, which is unlikely to hold in practice, as there is an extensive stream of research showing that managers manipulate earnings to meet or beat analysts' forecasts (see, e.g., Degeorge et al., 1999; Abarbanell and Lehavy 2003). They therefore suggest a revised model. To alleviate the issues associated with using an ex post estimate of SE using actual earnings, Sheng and Thevenot suggest (2012) using a GARCH model to estimate the squared error of the mean forecast, SE, using historical data only. Specifically, this method uses the time series of errors in the mean forecast to provide an estimate of their conditional variance. After estimating the GARCH model, one can obtain the conditional variance, which is then used as an ex ante estimate of SE in the expressions above (equation 1). Hence we refer to this model as the ST model. Note that both the BKLS and the ST model use the same equations to measure common, private, total information while the difference is how to calculate $\mathrm{SE}$ in the equations.

Even though it seems that the new model makes small changes only, it is suggested to have several benefits compared to the older version. For example, the new measure of uncertainty would, compared to other existing measures in the literature used to evaluate the implementation of IFRS, better capture both components of the theoretical construct and it is more stable and reliable in a variety of settings. It also has the advantage that it is based on information known to analysts at the time they make forecasts and not estimates.

To our knowledge, the ST model has not been used to evaluate the impact of IFRS in earlier studies. The only study that has used the new model, Barron, Sheng and Thevenot, (2012), concludes that it is superior to BKLS. For example, the study finds that information asymmetry and average information precision are more important factors than equity beta and firm size in determining firms' cost of capital. The seemingly great importance of these variables is not apparent when using the BKLS measure in the same way as when using the ST model.

\subsection{Public and private information as a basis for analysing the indented and unintended consequences of new accounting standards}

The most general assumption about the purpose of introducing new accounting standards is that this will lead to a reduction of the information asymmetry and therefore decrease firm uncertainty. However, Brüggemann et al. (2013) takes the view that the consequences of adopting standards are twofold. There are consequences that relate to the explicitly stated objectives by the regulator and those that are not. The consequences that can be traced directly to the achievement of the stated objective are called intended consequences and the consequences beyond this are called unintended. The rationale for dividing the effect between intended and unintended consequences is based on the knowledge that not all regulations will give the expected outcome and the outcome is often unexpected. In some cases outcomes are mostly unwanted.

Brüggemann et al. (2013) concentrate on three types of effects derived from the main foci of the prior literature: financial reporting effects, capital markets effects and macroeconomic effects. Studies looking at financial reporting effects are grouped into three subcategories: compliance and accounting choice studies, studies analysing the properties of accounting numbers, and value relevance studies. The analysis shows that in compliance and accounting choice studies there is often limited access to appropriate data but a general conclusion is that there exists a cross-country variation (Glaum Schmidt, Street, \& Vogel, 2013; Verriest, Gnaeremynck, \& Thornton, 2013; Cascino \& Gassen, 2012; Kvaal \& Nobes, 2010;2012). In regard to studies analysing the properties of accounting numbers the results are inconsistent. For example, there are studies focusing on common earning properties, finding that mandatory adoption of IFRS has no significant impact (Atwood, Drake, Myers, \& Myers, 2011) or even a negative impact (Ahmed, Neel, \& Wang, 2013; Callao \& Jarne, 2010). Analysing the studies focusing on comparability shows results all the way from an increase in comparability (Cascino \& Gassen, 2012) and a decrease in comparability (Lang, Maffett, \& Owens, 2010) to results showing that it depends on time, i.e., an adoption of IFRS gives more comparability the first year but the effect diminishes over time (Liao, Sellhorn, \& Skaife, 2012). 
The value relevance studies show more consensus that the adoption of IFRS has a positive impact on a general level. However, the adoption of IFRS also shows that this is not unconditionally unanimous. The positive impact is quite convincing in regard to the value relevance of equity (Aharony, Barniv, \& Falk, 2010; Barth, Landsman, Young, \& Zhuang, 2012) but uncertain in regard to the value relevance of the debt market (Barth et al., 2012; Wu \& Zhang, 2014,).

The studies looking at capital market effects are also analysed in different groups. Brüggemann et al. (2013) identify two groups of studies: those focusing on direct evidence and those focusing on indirect evidence on economic consequences in the capital market. The authors find that there is a general consensus that the adoption of IFRS has a positive impact both in regard to direct (Daske, Hail, Leuz, \& Verdi, 2008; Muller, Riedl, \& Sellhorn, 2011; Li 2010, DeFond, Hu, Hung, \& Li, 2011; Yu 2010, Brüggemann et al., 2013; Schleicher, Tahoun, \& Walker, 2010) as well as indirect effects (Landsman, Maydew, \& Thornock, 2012; Kim \& Li, 2011; Wang, 2011; Beuselinck et al., 2010; Byard et al., 2011; Horton et al., 2013; Panaretou, Shackleton, \& Taylor, 2013; Tan et al., 2011). The studies looking at the macroeconomic effects almost unanimously support, in the same way as the capital-market effects studies, a positive effect (Beneish \& Yohn, 2008; Amiram, 2012; Khurana \& Michas, 2011; Shima \& Gordon, 2011; Márquez-Ramos, 2011).

In general, the outcome of IFRS could go either way because IFRS has a stronger orientation toward fair value accounting than most previous national standards, which is likely to provide a better representation of a firm's underlying economic value and should therefore decrease information asymmetry for investors. However, the increased opportunities for managerial discretion associated with IFRS (e.g., Ormrod \& Taylor, 2004) could create a degree of uncertainty. The effect of IFRS on uncertainty may also depend on whether analysts use more public or private information (Heflin, Subramanyam, \& Zhang, 2003; Irani \& Karamanou, 2003). If public information is the primary source used, there should be less uncertainty because public information is available to all. However, if analysts seek to gain advantage by gathering private information in response to an increase in public information, policies for the improvement of accounting information may increase uncertainty. It could also be the case that analysts choose to 'herd' when earnings are more uncertain, leading to less forecast uncertainty for firms with less predictable earnings (Ramnath et al., 2008).

Using the BKLS model, Kim and Shi (2012); Beuselinck et al. (2010), Byard et al. (2011) and Yang (2011) empirically test how the financial analysts' information environment is affected by IFRS adoption. Table 1 summarises these four studies. Kim and Shi (2012) find that IFRS introduction improves analyst information sets and that both private and public information precision increase after IFRS introduction. Beuselinck et al. (2010) and Yang (2011) examine the impact of IFRS and use the BKLS to measure private and public information precision. They found a positive association between IFRS and public information precision, which is consistent with an increase in accounting quality. However, Beuselinck et al. (2010) suggest that the effect is more significant in countries in which IFRS entails a significant change, whereas Yang (2011) suggests that the improvement is more significant in countries that already have high-level disclosure standards. Yang (2011) examines whether analysts use more public or private information after IFRS adoption in 18 countries. Yang concludes that both public and private information increase after mandatory IFRS adoption and that the overall effect is a decrease in forecast uncertainty among analysts. Interestingly, public and private information increases more in common law countries than in civil law countries, indicating that dispersion can increase in some countries while decreasing in others. Additionally, Byard et al. (2011) focuses on strong versus low investor protection countries and finds that the positive impact on analyst information precision is mostly related to analysts in strong investor protection countries.

Table 1. Earlier studies using BKLS on IFRS adoption

\begin{tabular}{lllll}
\hline & Type of IFRS & Results & Year & Countries \\
\hline Kim and Shi (2012) & Voluntary & h, s and k improve & $1998-2004$ & 29 \\
Beuselink et al. (2010) & $\begin{array}{l}\text { Mandatory and } \\
\text { Voluntary IFRS }\end{array}$ & h and s improve & $2003-2007$ & 14 \\
Bard et al (2011) & $\begin{array}{l}\text { Mandatory and } \\
\text { Voluntary IFRS }\end{array}$ & $\begin{array}{l}\text { h, s and p improve in strong } \\
\text { investor protection countries }\end{array}$ & $2002-2006$ & 20 \\
Yang (2011) & Mandatory & $\begin{array}{l}\text { h, s and p improves and more in } \\
\text { common law countries }\end{array}$ & $2002-2007$ & 18 \\
\hline
\end{tabular}

Notes: This table summarises the four main studies using BKLS analyzing IFRS adoption. The results from these four studies show improvement in the information environment after IFRS adoption. $\mathrm{h}$ stands for public information, $\mathrm{s}$ private information, $\mathrm{k}$ is the sum of $\mathrm{h}$ and $\mathrm{s}$ while $\mathrm{p}$ is the relative use of public information. 
To sum up, these four studies find a positive effect on the analyst information environment using the BKLS model analysing the adoption of IFRS. In our research design we use this model as well as the more advanced ST model to analyse the impact of IFRS.

\section{Method and sample}

\subsection{The selection of countries}

Beginning with the financial year starting on or after 1 January 2005, all listed European Union (EU) companies "shall prepare their consolidated accounts in conformity with the international accounting standards [IAS]" (EU, 2002: Article 4). This means that these companies must apply IAS, International Financial Reporting Standards (IFRS) and Standing Interpretations Committee/International Financial Reporting Standards Interpretation Committee (SIC/IFRSIC) interpretations issued by the International Accounting Standards Board (IASB). The adoption of this standard constitutes what must be regarded as the single most significant change in accounting standards that have ever occurred in Europe and is typically referred to as the introduction of IFRS (for a comprehensive description of the implementation of IFRS, see for example Armstrong, Barth, Jagolinzer, Riedl, 2010).

The adoption of IFRS has led to substantial changes in how companies prepare their accounts in most, if not all, European countries. Obviously, such a major change can be regarded as an opportunity to examine various accounting methods' effect accounting quality. Therefore, in this study, we examine the impact of IFRS on accounting quality in five EU countries: Sweden, the UK, Germany, France and the Netherlands. We selected these particular countries because of their variability in characteristics of prior accounting standard, accounting histories, as well as strength of enforcement. The five countries have regulatory systems with different origins and display varying strength of enforcement (La Porta, Lopez-de-Silanes, Shleifer \& Vishny, 1998; Preiato et al., 2013). The varying financial accounting traditions of these countries (Nobes, 1983) reflect these differences, which is evident from Table 2. There has lately been a considerable amount of research about the influence of legal and institutional settings on accounting quality (e.g., Byard et al., 2011; Soderstrom \& Sun, 2007). This research is typically based on the assumption that accounting quality varies with legal and institutional setting, and that accounting quality affects analysts' ability to make accurate forecasts. The incentives facing reporting firms as well as firm-specific characteristics have also been emphasized as factors explaining whether IFRS is successfully implemented or not. Byard et al. (2011) and Jeanjean and Stolowy (2008), for example, stress the importance of the incentives facing firms regarding reporting and that these are influenced by legal institutions, firms' operating characteristics, market forces, and similar factors. It is therefore reasonable to, in line with Zeff (2007), assume that country-specific differences (e.g., business and financial culture, accounting culture, auditing culture and regulatory culture) have a decisive influence on the success of IFRS implementation.

Table 2. GAAP difference and enforcement

\begin{tabular}{lll}
\hline & GAAP-difference & Enforcement \\
\hline Sweden & 10 & 14 \\
Netherlands & 4 & 12 \\
France & 12 & 21 \\
Germany & 11 & 18 \\
United Kingdom & 1 & 24 \\
\hline
\end{tabular}

Notes: This table shows the GAAP-difference, i.e. the difference between prior local GAAP and IFRS, of the sample countries (Bae et al., 2008) and the strength of the enforcement of accounting rules in the same countries (Preito et al., 2010).

The impact of IFRS on accounting quality thus appears to vary among countries, making it unrealistic to assume that it would have the same effects on the level of uncertainty among analysts in all countries that introduce it. A number of studies, such as Barth et al. (2008), Byard et al. (2011), Daske et al. (2008) and Preiato et al. (2013), also argue that the enforcement of accounting standards is pivotal for the realisation of quality increases through the introduction of IFRS. Enforcement of accounting standards varies substantially among countries (La Porta et al., 1998). For example, there is much to suggest that the strength of accounting standard enforcement varies across countries (Preiato et al., 2013) and this enforcement strength influences managerial discretion. Common law countries (i.e., the UK and Ireland) seem in general to have stronger enforcement mechanisms than code law countries (i.e., the rest of the EU), as found by Francis, Khurana and Pereira (2003) and Hope (2003), among others. The international accounting literature also suggests a higher accounting quality in common law countries (Ali \& Hwang, 2000; Ball, Kothari, \& Robin, 2000; Leuz, Nanda \& Wysocki, 2003), and an influence of enforcement mechanisms on the quality of financial reporting under IFRS (Ball et al., 2000; Ball, 2006; Barth et al., 2008; Byard 
et al., 2011; Dao, 2005; Daske et al., 2008). Without the existence of effective enforcement mechanisms, Barth et al. (2008) conclude, the potential benefits of the introduction of IFRS are difficult to attain (cf. Byard et al., 2011; Preiato et al., 2013).

The quality of the accounting standard previously used in a given country also appears as an important factor in explaining whether IFRS leads to an improvement in accounting quality. With a prior standard of low quality, changing to a standard that better reflects a firm's underlying economic value is likely to lead to a more significant effect (Byard et al., 2011). The magnitude of differences between IFRS and the local GAAP that they have replaced varies considerably (Bae, Tan \& Welker, 2008; Nobes, 1983) and it is therefore reasonable to expect IFRS' effect on analyst performance to vary among countries. Our sample countries in Table 2 display variation on the dimensions of GAAP-difference and enforcement. The UK and the Netherlands exhibit the smallest GAAP-difference, whereas France, Germany and Sweden display larger differences. The UK is regarded as having strong enforcement. According to Preiato et al. (2013), Sweden and the Netherlands have relatively weak enforcement, whereas France and Germany have stronger enforcement. Because of the variation in both GAAP-difference and the variation in enforcement our five countries are likely to be representative for all countries adopting IFRS.

\subsection{Variables}

Analysts usually forecast the earnings per share (EPS) of a particular fiscal year several times before the actual figures are released. The frequency of the forecasts differs in accordance with the analyst. The Institutional Brokers' Estimate System (I/B/E/S) collects forecast data from individual analysts around the world once a month and uses those data to calculate statistics such as the mean, median, and standard deviation. Only the final estimates of the analysts are included in the monthly calculation. Thus, the $\mathrm{I} / \mathrm{B} / \mathrm{E} / \mathrm{S}$ database provides calculated statistics of analysts' EPS forecasts once a month. In this study, we utilise the general methodology for collecting forecast data (see, for example, Lang \& Lundholm, 1996) using the final calculated mean of an analyst's EPS forecasts before the first quarterly EPS report is released. For example, for a firm with a fiscal year end of December 31, 2009, we use the mean forecast calculated in March 2009 as the forecast data for the actual EPS on December 31, 2009. We use these basic data to calculate the expected squared error in the mean forecast (SE), the conditional variance, the expected sample variance in forecast (D) and the number of forecasts $(\mathrm{N})$ for both the BKLS and the ST model, using equations (1).

The accounting standard followed is a dummy variable for which 1 is used for IFRS and 0 is used for every other accounting standard. This variable is a firm-level variable, which means that early IFRS adopters are identified as IFRS users even though this usage is not mandatory. The variable is set to 1 one year after a firm's implementation of IFRS because analysts could not have based their adoption-year predictions on IFRS accounting, as the EPS predictions we use were formulated before the first IFRS-based quarterly report. The six control variables (see Table 3 ), selected on the basis of prior research into factors that normally affect analysts' performance (Lang \& Lundholm, 1996), are as follows: number of analysts, market value, trading volume, earnings surprise, profit/loss, and standard deviation of return on equity (std ROE).

Table 3. Independent variables

\begin{tabular}{|c|c|c|}
\hline Variable & Explanation & $\begin{array}{l}\text { Predicted sign of the } \\
\text { dependent variables }\end{array}$ \\
\hline Number of analysts & The number of analysts following a company. & + \\
\hline Market value & $\begin{array}{l}\text { Market value is measured as the company's market value at the } \\
\text { beginning of the fiscal year. }\end{array}$ & + \\
\hline Trading volume & $\begin{array}{l}\text { Trading volume refers to the company's absolute daily trading } \\
\text { volume during the first month of the fiscal year. }\end{array}$ & + \\
\hline Profit/Loss & $\begin{array}{l}\text { Loss, a dummy variable that takes the value of } 1 \text { if the company } \\
\text { reported a loss and } 0 \text { otherwise. }\end{array}$ & - \\
\hline Earnings surprise & $\begin{array}{l}\text { The absolute value of the year's earnings per share, minus the } \\
\text { previous year's earnings per share, scaled by the share price at } \\
\text { the beginning of the fiscal year. EPS } \mathrm{t}_{\mathrm{t}} \text { is the earnings per share } \\
\text { during period } \mathrm{t} \text { (of a given year), and } \mathrm{EPS}_{\mathrm{t}-1} \text { is the earnings per } \\
\text { share in period } \mathrm{t}-1 \text { (the previous year). }\end{array}$ & - \\
\hline Std ROE & $\begin{array}{l}\text { The company's standard deviation return on equity over the } \\
\text { previous three years. }\end{array}$ & - \\
\hline $\begin{array}{l}\text { IFRS-Accounting } \\
\text { standard followed }\end{array}$ & $\begin{array}{l}\text { A dummy variable that takes the value of } 1 \text { if the company used } \\
\text { IFRS for preparing last years' financial reports and } 0 \text { otherwise. }\end{array}$ & + \\
\hline
\end{tabular}

Notes: This table shows explanation of independent variables and their predicted signs. 
The number of analysts is determined by counting the analysts following the company and providing earnings forecasts in the month for which we are collecting data, again in line with Lang and Lundholm (1996). We control for firm size using market value and trading volume. Firm size is used in the literature as a proxy for several factors. Size should reflect information availability and therefore be positively related to forecast accuracy. Brennan and Hughes (1991) also found empirical evidence between firm size and analysts following a firm, and Lang and Lundholm (1993) found that firm size and performance variability likely correlate with disclosure policy. Market value is measured as the company's market value at the beginning of the fiscal year and is commonly used to control for size. However, we also utilise trading volume as a control for size because it may be more indicative of the number of analysts following a firm, as analysts are often paid indirectly through trading activity. Trading volume refers to the company's absolute daily trading volume during the first month of the fiscal year. Earnings surprise, which is the variation in a firm's results from one year to another, is calculated as the absolute value of the year's earnings per share minus the previous year's earnings per share, scaled by the share price at the beginning of the fiscal year. EPSt is the earnings per share during period $t$ (of a given year) and EPSt-1 is the earnings per share during period $\mathrm{t}-1$ (the previous year).

$$
\text { EarningsSurprise }=\frac{\left|E P S_{t}-E P S_{t-1}\right|}{\text { Stock price at the beginning of the fiscal year }}
$$

According to Lang and Lundholm (1996), earnings surprise controls for the likely effect that major events, such as a firm's introduction of a new product, have on forecasts. In these circumstances, realised earnings are most likely to deviate from expected earnings, and it is likely that analysts will not be able to make accurate forecasts.

Hope (2003) suggests that it is much more difficult to predict future earnings for firms with negative earnings. We therefore use a control variable, loss, a dummy variable that has a value of 1 if the company reported a loss and 0 otherwise. King, Pownall and Waymire (1990) found that the number of analysts following firms is likely to be related to variations in return. Fewer analysts follow firms that experience significant fluctuations in profitability. In other words, a negative relationship exists between the number of analysts and variations in profitability. Thus, standard deviation of return on equity is the final control variable in our regressions and it is measured as the company's return on equity over the previous three years.

\subsection{Sample}

Using the ST model, we need to use a GARCH model to estimate the conditional variance. Table 4 summarises the steps toward our final sample. We start with over 27,000 observations using the I/B/E/S database, selecting firms with analysts following and fiscal year equal to calendar year. The GARCH model needs a long time period to estimate the conditional variance and we therefore only select the firms with a consecutive 15 years or more of analyst forecasts (column 3 and 4 in Table 4). We also lose some observations running the GARCH model (column 5). Thereafter, we only select firms with observation during the IFRS adoption window, at least one year without IFRS and at least one year with IFRS (column 6 and 7). Further, we lose observations because we are not able to calculate public and private information using the BKLS or ST model (column 8). Finally, some firms also lack the variables IFRS (column 9) and StdROE (column 10). Our final sample consists of 2,162 observations from publicly traded companies in our five European countries during the period of 2002-2007.

Table 4. Sample selection

\begin{tabular}{|c|c|c|c|c|c|}
\hline & $\begin{array}{l}\text { All firms in IBES } \\
\text { registered between the } \\
\text { years } 1990-2011 \text { with } \\
\text { analyst following and } \\
\text { fiscal year = calendar year }\end{array}$ & $\begin{array}{l}\text { Subtract } \\
\text { companies } \\
\text { with less than } \\
15 \text { years. }\end{array}$ & Subtotal & $\begin{array}{l}\text { Computatio } \\
\text { nal errors } \\
\text { with } \\
\text { Garch-mod } \\
\text { el }\end{array}$ & Subtotal \\
\hline Sweden & 3203 & -2226 & 977 & -1 & 976 \\
\hline Netherlands & 2905 & -1471 & 1434 & -1 & 1433 \\
\hline France & 6116 & -4042 & 2074 & -18 & 2056 \\
\hline Germany & 5867 & -4635 & 1232 & -8 & 1224 \\
\hline UK & 9005 & -6081 & 2924 & -2 & 2922 \\
\hline Total & 27096 & & 8641 & & 8611 \\
\hline
\end{tabular}


Table 4. Sample selection, continued

\begin{tabular}{llllll}
\hline $\begin{array}{l}\text { Only observations } \\
\text { for the examined } \\
\text { period of } \\
2002-2007\end{array}$ & Subtotal & $\begin{array}{l}\text { Not able to } \\
\text { calculate } \\
\text { p,h,s }\end{array}$ & $\begin{array}{l}\text { Lacking } \\
\text { variable } \\
\text { IFRS }\end{array}$ & $\begin{array}{l}\text { Lacking } \\
\text { variable stdROE }\end{array}$ & $\begin{array}{l}\text { Final } \\
\text { sample }\end{array}$ \\
\hline-705 & 271 & -35 & -1 & -17 & 218 \\
-1011 & 422 & -16 & -4 & -20 & 382 \\
-1438 & 618 & -44 & 0 & -2 & 572 \\
-875 & 349 & -37 & -1 & -24 & 287 \\
-2066 & 856 & -82 & -6 & -65 & 703 \\
\hline Total & 2516 & & & & 2162 \\
\hline
\end{tabular}

Notes: This table shows the sample selection procedure and how the final sample was constructed.

\subsection{Models and estimation techniques}

We estimate the following equation:

$$
\begin{aligned}
& Q_{\theta}\left(\mathrm{h}, \mathrm{s}, \mathrm{k}_{i t}\right)=\alpha+\beta_{1} \text { Number of analysts }_{i t}+\beta_{2} \text { Market value }_{i t}+\beta_{3} \text { Trading volume }_{i t} \\
& +\beta_{4} \text { Profit } / \text { Loss }_{i t}+\beta_{5} \text { Earnings surprise }_{i t}+\beta_{6} \text { Std dev ROE }_{i t}+\beta_{7} \text { (IFRS) Accounting standard followed } \\
& +\beta+\varepsilon_{i t}
\end{aligned}
$$

in which the variable Number of analysts is the number of analysts making a forecast of a company. Market value is the market value measured as the company's market value at the beginning of the fiscal year. Trading volume refers to the company's absolute daily trading volume during the first month of the fiscal year. Profit/Loss is a dummy variable that takes the value of 1 if the company reported a loss and 0 otherwise. Earnings surprise is the absolute value of the year's earnings per share minus the previous year's earnings per share, scaled by the share price at the beginning of the fiscal year. Std ROE is the company's standard deviation return on equity over the previous three years. IFRS-Accounting standard followed is a dummy variable that takes the value of 1 if the company used IFRS for preparing last years' financial reports and 0 otherwise. All continuous variables are winsorised at the 1st and 99th percentiles and we take logarithm transformation for our analysis. All of these variables are regressed respectably with the dependent variables $\mathrm{h}$ (COMMON information), s (PRIVATE information) and $\mathrm{k}$ (TOTAL information), estimated using the BKLS and ST models, respectively.

\section{Results}

Table 5 provides descriptive statistic for our sample. Note the values for common and private information between the BKLS model and the ST model. The mean for common information is much higher for the BKLS model than the ST model (6.42 versus 3.19), while the mean for private information is almost the same for the two models. However, the median for common information is higher for the ST model than the BKLS model 1.39 versus 1.09). Table 5 further describe descriptive statistic for all the independent variables.

Table 5. Descriptive statistics

\begin{tabular}{llllll}
\hline Variable & Mean & Median & Std. Dev & Min & Max \\
\hline Common - BKLS & 6.42 & 1.09 & 102.59 & 0 & 6200 \\
Common - ST & 3.19 & 1.39 & 18.80 & -0.11 & 1120.82 \\
Private - BKLS & 6.03 & 1.29 & 13.44 & 0 & 356.30 \\
Private - ST & 5.97 & 1.26 & 14.55 & 0 & 614.18 \\
Market value & 10,426 & 1,440 & 29,924 & 2.2 & 994,930 \\
Trading volume & 34,649 & 4,750 & 120,668 & 0 & 570,0000 \\
Earning surprise & 0.08 & 0.06 & 0.12 & 0 & 4.19 \\
Std. ROE & 8.32 & 3.61582 & 25.12 & 0.11 & 798.88 \\
Loss & 0.06 & 0 & 0.24 & 0 & 1 \\
Following & 13.05 & 11 & 8.70 & 2 & 48 \\
IFRS & 0.34 & 0 & 0.47 & 0 & 1 \\
\hline
\end{tabular}

Notes: This table shows descriptive statistic for the variables. 
Table 6 provides the correlations for all of the variables. All of our six dependent variables are significantly positively correlated with each other, indicating a relationship whereby an increase in one correlates with an increase in another. One interpretation is thereby that an increase in public information leads to an increase in private information using both the BKLS and ST models. The two types of information thereby complement each other. Additionally, within each model both private and common information correlates positively, as expected for Total information. However, when examining our variable of interest, IFRS, we find only significant correlation between COMMON-BKLS and TOTAL-BKLS. This is an indication that IFRS adoption matters for the information environment using the BKLS model but not using the ST model. The table also shows the six independent variables. As expected, Market value correlates significantly positively with all six dependent variables, whereas Loss and Std ROE correlates significantly negatively with the six dependent variables. These correlations all occur in the expected direction, as observed earlier in Table 3. Larger firms have better information environments while loss-making and volatility in profitability makes the information environment worse. The signs also indicate that the number of analysts and trading volume are associated with improved information environment whereas earnings surprises appear to worsen the information environment. There may be some problems with multicollinearity. The highest correlation among the independent variables is 0.59 (for market value and number of analysts) and 0.58 (for market value and trading volume). When we check all variance inflation factors (VIF), we find high values for the latter. These two variables (market value and trading volume) both control for size, and because market value is the most common control variable for size we omit trading volumes from our models. Otherwise, the variance inflation factor (VIF) values are lower than 2. Thus, there is no reason to believe that other correlations affect the estimations.

Table 6. Correlations matrix

\begin{tabular}{lllllll}
\hline Variable & 1 & 2 & 3 & 4 & 5 & 6 \\
\hline 1. Common - BKLS & 1.00 & & & & & \\
2. Common - ST & $0.38^{* * *}$ & 1.00 & & & & \\
3. Private - BKLS & $0.27^{* * *}$ & $0.11^{* * *}$ & 1.00 & & & \\
4. Private - ST & $0.12^{* * *}$ & $0.63^{* * *}$ & $0.35^{* * *}$ & 1.0 & & \\
5. Total - BKLS & $0.49^{* * * *}$ & $0.32^{* * *}$ & $0.86^{* * *}$ & $0.25^{* * *}$ & 1.00 & \\
6. Total - ST & $0.31^{* * *}$ & $0.81^{* * *}$ & $0.22^{* * *}$ & $0.85^{* * *}$ & $0.37^{* * *}$ & 1.00 \\
7. IFRS & $0.09^{* * *}$ & 0.03 & 0.03 & -0.01 & $0.08^{* * *}$ & 0.02 \\
8. Market value & $0.08^{* *}$ & $0.10^{* * *}$ & $0.18^{* * *}$ & $0.15^{* * *}$ & $0.17^{* * *}$ & $0.14^{* * *}$ \\
9. Trading volume & -0.02 & $0.09^{* * *}$ & -0.03 & $0.13^{* * *}$ & -0.01 & $0.13^{* * *}$ \\
10. Following & 0.02 & $0.08^{* *}$ & $0.21^{* * *}$ & $0.18^{* * *}$ & $0.17^{* * *}$ & $0.14^{* * *}$ \\
11. Earnings surprise & $0.09^{* *}$ & 0.01 & $-0.24^{* * *}$ & $-0.10^{* * *}$ & $-0.17^{* * *}$ & $-0.04^{*}$ \\
12. Loss & $-0.27^{* * *}$ & $-0.24^{* * *}$ & $-0.25^{* * *}$ & $-0.22^{* * *}$ & $-0.36^{* * *}$ & $-0.33^{* * *}$ \\
13. Std ROE & $-0.18^{* * *}$ & $-0.19^{* * *}$ & $-0.12^{* * *}$ & $-0.16^{* * *}$ & $-0.20^{* * *}$ & $-0.21^{* * *}$ \\
\hline
\end{tabular}

Table 6. Correlations matrix, continued

\begin{tabular}{lllllll}
\hline Variable & 7 & 8 & 9 & 10 & 11 & 12 \\
\hline 7. IFRS & 1.00 & & & & & \\
8. Market value & $0.10^{* * *}$ & 1.00 & & & & \\
9. Trading volume & -0.03 & $0.58^{* * *}$ & 1.00 & & & \\
10. Following & $0.07^{* * *}$ & $0.59^{* * *}$ & $0.46^{* * *}$ & 1.00 & & \\
11. Earnings surprise & 0.02 & $-0.16^{* * *}$ & $-0.09^{* * *}$ & $-0.14^{* * *}$ & 1.00 & \\
12. Loss & $-0.08^{* * *}$ & $-0.09^{* * *}$ & $-0.03^{*}$ & $-0.08^{* *}$ & $0.12^{* * *}$ & 1.00 \\
13. Std ROE & 0.03 & $-0.05^{*}$ & $0.11^{* * *}$ & -0.02 & 0.03 & $0.20^{* * *}$ \\
\hline
\end{tabular}

${ }^{* * *} \mathrm{p}<0.001 .{ }^{* *} \mathrm{p}<0.01 .{ }^{*} \mathrm{p}<0.05$.

Notes: This table shows the correlation of all dependent and independent variables.

Table 7 shows our six regressions. Columns 1 and 2 show regressions with COMMON information while columns 3 and 4 show PRIVATE information and columns 5 and 6 show TOTAL information. Columns 1,3 and 5 show the 
BKLS model while columns 2, 4 and 6 show the ST model. The strongest predictors of the information environment in both models (BKLS and ST) are the control variables market of value, profit/loss and Std ROE, which have the expected signs in all models. The control variable number of analysts following a company shows a mixed result. In column 1, the number of analysts has a significantly negative effect on COMMON information in the BKLS model and a significantly positive effect on PRIVATE information in both models as well as on total information in the ST model. One interpretation of these later results could be of the analysts' use of PRIVATE or COMMON information, as discussed in section 2.2. Analysts may seek to gain advantage by gathering private information in response to an increase in common information, leading to less precision in common information and better precision in private information. The surprisingly significantly positive effect on earnings surprise for common information may be explained by the fact that analysts choose to 'herd' when earnings are more uncertain, leading to less forecast uncertainty for firms with less predictable earnings (Ramnath et al., 2008).

Table 7. OLS regressions

\begin{tabular}{lllllll}
\hline Variable & COMMON & \multicolumn{3}{c}{ PRIVATE } & TOTAL \\
& BKLS & ST & BKLS & ST & BKLS & ST \\
\hline IFRS & $0.211^{* *}$ & 0.069 & -0.002 & -0.262 & $0.130^{*}$ & -0.003 \\
& $(2.83)$ & $(0.86)$ & $(-0.02)$ & $(-1.52)$ & $(1.96)$ & $(-0.04)$ \\
Market value & $0.130^{* * *}$ & $0.124^{* * *}$ & $0.114^{*}$ & $0.197^{* *}$ & $0.117^{* * *}$ & $0.171^{* * *}$ \\
& $(4.62)$ & $(4.12)$ & $(2.35)$ & $(3.04)$ & $(4.68)$ & $(5.27)$ \\
Following & $-0.018^{* *}$ & 0.005 & $0.026^{*}$ & $0.069^{* * *}$ & -0.002 & $0.017^{*}$ \\
& $(-2.95)$ & $(0.75)$ & $(2.43)$ & $(4.88)$ & $(-0.34)$ & $(2.37)$ \\
Earnings surprise & $0.187^{* * *}$ & $0.098^{* *}$ & $-0.395^{* * *}$ & $-0.129^{*}$ & $-0.093^{* * *}$ & 0.062 \\
& $(6.48)$ & $(3.19)$ & $(-7.95)$ & $(-1.95)$ & $(-3.66)$ & $(1.88)$ \\
Loss & $-1.888^{* * *}$ & $-1.444^{* * *}$ & $-3.331^{* * *}$ & $-2.279^{* * *}$ & $-2.495^{* * *}$ & $-2.247^{* * *}$ \\
& $(-10.81)$ & $(-7.58)$ & $(-11.08)$ & $(-5.67)$ & $(-16.11)$ & $(-11.17)$ \\
Std ROE & $-0.206^{* * *}$ & $-0.253^{* * *}$ & $-0.121^{*}$ & $-0.377^{* * *}$ & $-0.162^{* * *}$ & $-0.287^{* * *}$ \\
& $(-6.30)$ & $(-7.80)$ & $(-2.15)$ & $(-5.02)$ & $(-5.61)$ & $(-7.64)$ \\
Constant & -0.086 & -0.058 & $-1.730^{* *}$ & -1.194 & 0.268 & 0.481 \\
& $(-0.24)$ & $(-0.14)$ & $(-2.80)$ & $(-1.44)$ & $(0.84)$ & $(1.16)$ \\
$\mathrm{N}$ & 2,162 & 2,162 & 2,162 & 2,162 & 2,162 & 2,162 \\
R-squared & 0.15 & 0.21 & 0.25 & 0.22 & 0.28 & 0.33 \\
F-statistics & $8.80^{* * *}$ & $12.30^{* * *}$ & $16.12^{* * *}$ & $13.47^{* * *}$ & $18.54 * * *$ & $23.37^{* * *}$ \\
Industry effect & Yes & Yes & Yes & Yes & Yes & Yes \\
Country effect & Yes & Yes & Yes & Yes & Yes & Yes \\
\hline Co* & & & & & &
\end{tabular}

$\mathrm{p}<0.001 .^{* *} \mathrm{p}<0.01{ }^{*} \mathrm{p}<0.05$

Notes: This table shows the results from our six regressions. Columns 1 and 2 show regressions with COMMON information while columns 3 and 4 show PRIVATE information and columns 5 and 6 show TOTAL information. Columns 1, 3 and 5 show the BKLS model while columns 2, 4 and 6 show the ST model.

Overall, the models have reasonable explanatory power with R-squared ranging from 0.15 to 0.28 per cent for the BKLS model and 0.21 to 0.33 per cent for the ST model. F-statistics show that all models are significant.

Our main variable of interest, IFRS, is only significant in two of the six models, showing that IFRS adoption only has a significant effect on the information environment using the BKLS model to measure COMMON (public information) and TOTAL ( $<<0.05)$ (public plus private information). This is in line with earlier research (Kim \& Shi, 2012; Beuselinck et al., 2010; Byard et al., 2011; Yang, 2011). Thus, running the BKLS model on our sample, we find the same results as these earlier studies and confirm earlier results that IFRS adoption improves the information environment. However, Table 7 shows the ST models and in these models IFRS is not significant. Thus, when using a more developed model, we find no significant results that IFRS can improve the information environment for analysts. Earlier research results obtained by using the BKLS model can therefore be interpreted as spurious. 


\section{Robustness analysis}

As an alternative procedure, we have also estimated our equations using median regressions. As OLS is sensitive to skewness and outliers in the sample, all of the continuous variables were winsorised at the 1st and 99th percentiles and we took logarithm transformation for our analysis. When running median regressions as a robustness analysis we do not winsorise or take logarithm transformations of the variables. The results from the median regressions are shown in Table 8. Although the significant effect on TOTAL information using the BKLS model in the OLS regression has disappeared, our main results are confirmed when using median regressions. IFRS is only significant using the BKLS model on COMMOM information but not using the ST model.

Table 8. Median regressions

\begin{tabular}{lcccccc}
\hline Variable & \multicolumn{2}{c}{ COMMON } & \multicolumn{2}{c}{ PRIVATE } & \multicolumn{2}{c}{ TOTAL } \\
& BKLS & ST & BKLS & ST & BKLS & ST \\
\hline IFRS & $0.275^{* *}$ & 0.057 & -0.019 & -0.101 & 0.456 & 0.231 \\
& $(2.79)$ & $(0.45)$ & $(-0.07)$ & $(-0.33)$ & $(1.31)$ & $(0.63)$ \\
Market value & $0.000^{* * *}$ & $0.000^{* * *}$ & 0.000 & $0.000^{*}$ & $0.000^{*}$ & $0.000^{* *}$ \\
& $(4.03)$ & $(3.21)$ & $(0.47)$ & $(2.02)$ & $(2.52)$ & $(3.12)$ \\
Following & -0.005 & 0.012 & 0.034 & $0.073^{* * *}$ & 0.026 & $0.103^{* * *}$ \\
& $(-0.72)$ & $(1.38)$ & $(1.81)$ & $(3.34)$ & $(1.02)$ & $(3.90)$ \\
Earnings surprise & $-0.773^{* * *}$ & $2.654^{* *}$ & $-6.535^{* * *}$ & -1.647 & $-10.901 * * *$ & -0.626 \\
& $(-1.17)$ & $(3.15)$ & $(-3.72)$ & $(-0.81)$ & $(-4.69)$ & $(-0.25)$ \\
Loss & $-1.664^{* *}$ & $-0.907^{* *}$ & -1.097 & -0.277 & $-2.522^{* *}$ & -1.196 \\
& $(-2.82)$ & $(-3.02)$ & $(-1.75)$ & $(-0.38)$ & $(-3.04)$ & $(-1.36)$ \\
Std ROE & $-0.013^{* * *}$ & $-0.017^{* *}$ & -0.007 & -0.017 & -0.025 & $-0.055^{* * *}$ \\
& $(-3.05)$ & $(-3.08)$ & $(-0.60)$ & $(-1.22)$ & $(-1.64)$ & $(-3.36)$ \\
Constant & $1.376^{* * *}$ & 0.801 & 1.480 & $2.464^{*}$ & $3.723^{* *}$ & $5.283^{* * *}$ \\
& $(3.79)$ & $(1.73)$ & $(1.53)$ & $(2.20)$ & $(2.91)$ & $(3.88)$ \\
N & 2,162 & 2,162 & 2,162 & 2,162 & 2,162 & 2,162 \\
Pseudo R-squared & 0.06 & 0.11 & 0.07 & 0.14 & 0.10 & 0.17 \\
Industry effect & Yes & Yes & Yes & Yes & Yes & Yes \\
Country effect & Yes & Yes & Yes & Yes & Yes & Yes \\
\hline
\end{tabular}

${ }^{* * *} \mathrm{p}<0.001 .{ }^{* *} \mathrm{p}<0.01 .{ }^{*} \mathrm{p}<0.05$.

Notes: This table shows the results from the median regressions. Columns 1 and 2 show regressions with COMMON information while columns 3 and 4 show PRIVATE information and columns 5 and 6 show TOTAL information. Columns 1, 3 and 5 show the BKLS model while columns 2, 4 and 6 show the ST model.

Noteworthy, by using the two models at same dataset we find that the direction of the relation between IFRS adoption and the precision of information are the same between the two models (except for TOTAL information in the OLS regressions), however finding only significant relation with the BKLS model for COMMON and TOTAL information. These results about the direction of the relation between IFRS and information environment is in line with the only other study so far that used both BKLS and ST for analysing a single dataset, i.e. Barron, Sheng and Thevenot (2013). They conclude, when examining the cost of capital that the results from the two models are generally consistent in terms of the direction of the relations, but the statistical and economic significance are much lower when using the BKLS model because the new model is subject to less measurement error.

\section{Conclusions}

In summary, our results demonstrate that IFRS impact on accounting quality measured as financial analysts' information environment depends on which model is used. Using the same model as earlier research (the BKLS model), our results confirm earlier studies (Kim \& Shi, 2012; Beuselinck et al., 2010; Byard et al., 2011 and Yang, 2011) that IFRS adoption improves the information environment for analysts. However, when using a more developed model (ST, Sheng \& Thevenot, 2012), no such improvement (nor a deterioration) can be found. The latter 
model is much more realistic, capturing analysts' information environment by measuring analyst forecasts ex ante and not ex post as BKLS does.

This study is a direct answer to the urging of Brüggemann et al. (2013) to use alternative research designs to shed light on the mismatch of empirical evidence and the effects of IFRS. Brüggemann et al. (2013) review the literature on both the intended and unintended consequences of mandatory IFRS adoption. Empirical research on the intended consequences generally fails to document an increase in the comparability or transparency of financial statements. For example, concerning the compliance of financial reports after mandatory IFRS adoption, Kvaal and Nobes (2010) and Kvaal and Nobes (2012) find great cross-country variation in the reports and that these variations persist for several years after mandatory IFRS adoption. These results would diminish the ability to compare financial reports from different countries. Additionally, Brüggemann et al. (2013) note that studies analysing common earnings properties, such as earnings smoothing, conditional conservatism or discretionary accruals, find that mandatory IFRS adoption either has no significant impact (Atwood et al., 2011) or even a negative effect (Ahmed et al., 2013; Callao \& Jarne, 2010). These and other empirical studies are inconsistent with mandatory IFRS adoption unanimously enhancing the transparency or comparability of financial statements. On the other hand, there is extensive evidence of positive effects on capital markets. Research shows both direct effects (see for example Daske et al., 2008; DeFond et al., 2011) and indirect effects (for example Horton et al., 2013; Tan et al., 2011) leading mandatory IFRS adoption to yield capital markets benefits. To sum up, the empirical evidence is inconsistent and Brüggemann et al. (2013) calls for other research designs to understand this inconsistency. We have in this study shed some light on this inconsistency puzzle by applying two different models to measure the precision of analysts' information. We use in this study a two-step development of a model designed to measure both a company's public and private information. The earlier version of the model (BKLS) has been used in prior IFRS studies, which show nearly unanimous support for a positive effect of the adoption of IFRS. The latter version (ST) of the model has not, to our knowledge, been used in this type of study. Both of these models are based on financial analysts' data and are measured using the analyst information environment, which in turn is used as a proxy for accounting quality. The main differences between the two models is that the ST model uses only data known to financial analysts when they make the forecast while the BKLS model calculates the uncertainty among analysts at the time when the actual result is released, making it unreliable in capturing uncertainty among analysts when they make their forecasts. The ST model is therefore developed to give more certainty in the measurement of both public and private information. The ability to obtain information about the level of public and private information gives us a possibility to analyse together the intended and unintended consequences of the adoption of IFRS. By using both models on the same dataset we are able to analyse the consequences of small changes in methods.

Our results demonstrate that IFRS impact on accounting quality measured as financial analysts' information environment depends on the model used.

We make several contributions to the existing literature. First, investors and accounting researchers have long been concerned with the quality of the information environment faced by market participants. Our study questions earlier results that IFRS adoption improves the overall information environment faced by an important group of information users, financial analysts. Second, using the ST model for the first time in studying the effect of IFRS adoption, we add a developed analysis to the already vast literature on this matter. Third, by comparing the results between the BKLS model and ST model we can create awareness about the method effect as well as a possible explanation for the empirical inconsistency in the results within the IFRS research. Fourth, the study gives substance to the question of whether international accounting standards meet the regulatory objectives, which are highly important for future decisions regarding the regulation of the capital market.

Our study also comes with limitations. First, there are not many studies which have used the two models with the same data. Accordingly, an in depth evaluation of them has not been done. Barron, Sheng and Thevenot (2013) is an exception. They conclude, when examining the cost of capital that the results from the two models are generally consistent in terms of the direction of the relations, but the statistical and economic significance are much lower when using the BKLS model. The reason they suggest is that the ST-model is subject to less measurement error. In line with this we also find, in general, that the direction of the relation between IFRS adoption and the precision of information is the same between the two models. However, we only find a significant relation using the BKLS model for estimating common and total information. We therefore recommend that future research use both models in other settings in which the BKLS model has earlier been used to compare the results between the models. Second, while the ST model might provide an improvement over the BKLS model, it has certain limitations as well. The GARCH estimation requires a long time-series of data and hence, our sample includes primarily large and firms with a tradition of high number of analysts following. Therefore, our results may not be generalizable to smaller or 
short-lived firms. Also our measures of the information environment are based on analysts' forecasts and hence, do not necessarily reveal information characteristics of the investor community at large. Future research might nevertheless find it fruitful to follow the call of Brüggemann et al. (2013) to examine whether research design might explain the large discrepancy in results from IFRS adoption studies. This study has indicated that such method effect exists and such an effect has major consequences for how we can interpret the results from prior research on the effects of IFRS adoption.

\section{References}

Abarbanell, J., \& Lehavy, R. (2003). Biased forecasts or biased earnings? The role of reported earnings in explaining apparent bias and over/underreaction in analysts' earnings forecasts. Journal of Accounting \& Economics, 36(1-3), 105. http://dx.doi.org/10.1016/j.jacceco.2003.11.001

Abarbanell, J., Lanen, W., \& Verrecchia, R. (1995). Analysts' forecasts as proxies for investor beliefs in empirical research. Journal of Accounting and Economics, 20(1), 31-60. http://dx.doi.org/10.1016/0165-4101(94)00392-I

Aharony, J., Barniv, R., \& Falk, H. (2010). The Impact of Mandatory IFRS Adoption on Equity Valuation of Accounting Numbers for Security Investors in the EU. European Accounting Review, 19(3), 535-578. http://dx.doi.org/10.1080/09638180.2010.506285

Ahmed, A. S., Neel, M., \& Wang, D. (2013). Does Mandatory Adoption of IFRS Improve Accounting Quality? Preliminary Evidence. Contemporary Accounting Research, 30(4), 1344-1372. http://dx.doi.org/10.1111/j.1911-3846.2012.01193.x

Ali, A., \& Hwang, L. (2000). Country-Specific Factors Related to Financial Reporting and the Value Relevance of Accounting Data, Journal of Accounting Research, 38(1), 1-21. http://dx.doi.org/10.2307/2672920

Amiram, D. (2012). Financial Information Globalization and Foreign Investment Decisions. Journal Of International Accounting Research, 11(2), 57-81. http://dx.doi.org/10.2308/jiar-50282

Armstrong, C. S., Barth, M. E., Jagolinzer, A. D., \& Riedl, E. J. (2010). Market Reaction to the Adoption of IFRS in Europe. The Accounting Review, 85(1), 31-61. http://dx.doi.org/10.2308/accr.2010.85.1.31

Atwood, T. J., Drake, M. S., Myers, J. N., \& Myers, L. A. (2011). Do earnings reported under IFRS tell us more about future earnings and cash flows?. Journal Of Accounting \& Public Policy, 30(2), 103-121. http://dx.doi.org/10.1016/j.jaccpubpol.2010.10.001

Bae, K., Tan, H., \& Welker, M. (2008). International GAAP differences: the impact on foreign analysts. The Accounting Review, 83(3), 593-628. http://dx.doi.org/10.2308/accr.2008.83.3.593

Ball, R., Kothari, S., \& Robin, A. (2000). The effect of international institutional factors on properties of accounting earnings. Journal of Accounting and Economics, 29(1), 1-51. http://dx.doi.org/10.1016/S0165-4101(00)00012-4

Ball, R. (2006) International Financial Reporting Standards (IFRS): pros and cons for investors. Accounting \& Business Research, 36(1), 5-27.

Barron, O., Kim, O., Lim, S., \& Stevens, D. (1998). Using analysts' forecasts to measure properties of analysts' information environment. The Accounting Review, 73, 421-433.

Barron, O.E., Sheng, X., \& Thevenot, M. (2012). The Information Environment and Cost of Capital. http://dx.doi.org/10.2139/ssrn.2099825

Barron, O.E., Byard, D., Kile, C., \& Riedl, E.J. (2002). High-technology intangibles and analysts' forecasts. Journal of Accounting Research 40: 289-312. http://dx.doi.org/10.1111/1475-679X.00048

Barth, M. E., Landsman, W. R., Young, D., \& Zhuang, Z. (2012). Relevance of differences between net income based on IFRS and domestic standards for European firms. http://dx.doi.org/10.2139/ssrn.1837003

Barth, M.E., Landsman, W.R., \& Lang, M. H. (2008). International accounting standards and accounting quality. Journal of Accounting Research 46(3), 467-498. http://dx.doi.org/10.1111/j.1475-679X.2008.00287.x

Beneish, M. D., \& Yohn, T. L. (2008). Information friction and investor home bias: A perspective on the effect of global IFRS adoption on the extent of equity home bias. Journal Of Accounting \& Public Policy, 27(6), 433-443. http://dx.doi.org/10.1016/j.jaccpubpol.2008.09.001

Beuselinck, C., Joos, P., Khurana, I., \& Van der Meulen, S. (2010). Mandatory IFRS Reporting and Stock Price Informativeness. Working paper, Tilburg University and University of Missouri at Columbia. 
Botosan, C.A., \& Stanford, M. (2005). Managers' motives to withhold segment disclosures and the effect of SFAS No. 131 on analysts' information environment. The Accounting Review 80: 751-771. http://dx.doi.org/10.2308/accr.2005.80.3.751

Block, S. (1999). A study of financial analysts: practice and theory. Financial Analysts Journal, 55(4), 86-95. http://dx.doi.org/10.2469/faj.v55.n4.2288

Brennan, M., \& Hughes, P. (1991). Stock Prices and the Supply of Information. Journal of Finance, 46(5), 1665-1691. http://dx.doi.org/10.1111/j.1540-6261.1991.tb04639.x

Brüggemann, U., Hitz, J., \& Sellhorn, T. (2013). Intended and Unintended Consequences of Mandatory IFRS Adoption: A Review of Extant Evidence and Suggestions for Future Research. European Accounting Review, 22(1), 1-37. http://dx.doi.org/10.1080/09638180.2012.718487

Byard, D., Li, Y., \& Yu, Y. (2011). The Effect of Mandatory IFRS Adoption on Financial Analysts' Information Environment, Journal of Accounting Research, 49(1), 69-96. http://dx.doi.org/10.1111/j.1475-679X.2010.00390.x

Callao, S., \& Jarne, J. (2010). Have IFRS affected earnings management in the European Union? Accounting in Europe, 7(2), 159-189. http://dx.doi.org/10.1080/17449480.2010.511896

Cascino, S., \& Gassen, J. (2012). Comparability Effects of Mandatory IFRS Adoption. Working paper, London School of Economics and Humboldt University of Berlin.

Clement, M., Frankel, R., \& Miller, J. (2003). Confirming management earnings forecasts, earnings uncertainty, and stock returns. Journal of Accounting Research, 41(4), 653-679. http://dx.doi.org/10.1111/1475-679X.00119

Dao, T. (2005). Monitoring Compliance with IFRS: Some Insights from the French Regulatory System. Accounting in Europe, 2(1), 107-135. http://dx.doi.org/10.1080/09638180500378980

Daske, H., Hail, L., Leuz, C., \& Verdi, R. (2008). Mandatory IFRS Reporting around the World: Early Evidence on the Economic Consequences. Journal of Accounting Research, 46(5), 1085-1142. http://dx.doi.org/10.1111/j.1475-679X.2008.00306.x

DeFond, M., Hu, X., Hung, M., \& Li, S. (2011). The impact of IFRS adoption on foreign mutual fund ownership: the role of comparability, Journal of Accounting and Economics 51(3), 240-258. http://dx.doi.org/10.1016/j.jacceco.2011.02.001

Degeorge, F., Patel, J., \& Zeckhauser, R. (1999). Earnings management to exceed thresholds. Journal of Business, 72(1), 1-33. http://dx.doi.org/10.1086/209601

Doukas, J.A., Kim, C., \& Pantzalis, C. (2006). Divergence of opinion and equity returns. Journal of Financial and Quantitative Analysis 41: 573-606. http://dx.doi.org/10.1017/S0022109000002544

EU. (2002). European Union, EC regulation No 1606/2002. Available at: http://eur-lex.europa.eu

Francis, J., Khurana, I., \& Pereira, R. (2003). The role of accounting and auditing in corporate governance and the development of financial markets around the world. Asia-Pacific Journal of Accounting and Economics, 10, pp. 1-30. http://dx.doi.org/10.1080/16081625.2003.10510613

Glaum, M., Baetge, J., Grothe, A., \& Oberdorster, T. (2013). Introduction of International Accounting Standards, disclosure quality and accuracy of analysts' earnings forecasts. European Accounting Review , 22(1), 79-116. http://dx.doi.org/10.1080/09638180.2011.558301

Glaum, M., Schmidt, P., Street, D. L., \& Vogel, S. (2013). Compliance with disclosures required by IFRSs across 17 European countries: company-level and country-level determinants. Accounting and business research, 43(3), 163-204.

Heflin, F., Subramanyam K., \& Zhang, Y. (2003). Regulation FD and the financial information environment: Early evidence. The Accounting Review, 78(1), 1-37. http://dx.doi.org/10.2308/accr.2003.78.1.1

Hope, O. (2003). Disclosure practices, enforcement of accounting standards, and analysts' forecast accuracy: An international study. Journal of Accounting Research, 41(2), 235-272. http://dx.doi.org/10.1111/1475-679X.00102

Horton, J., Serafeim, G., \& Serafeim, I. (2013). Does mandatory IFRS adoption improve the information environment? $\quad$ Contemporary Accounting Research, 30(1), 388-423. http://dx.doi.org/10.1111/j.1911-3846.2012.01159.x 
IASB. (2010). International Accounting Standards Board, Conceptual Framework. Available at: http://www.ifrs.org

Irani, A., \& Karamanou, I. (2003). Regulation Fair Disclosure, analyst following, and analyst forecast dispersion. Accounting Horizons, 17(1), 15-29. http://dx.doi.org/10.2308/acch.2003.17.1.15

Jeanjean, T., \& Stolowy, H. (2008). Do accounting standards matter? An exploratory analysis of earnings management before and after IFRS adoption. Journal of Accounting and Public Policy, 27(6), 480-494. http://dx.doi.org/10.1016/j.jaccpubpol.2008.09.008

Johnson, T. (2004). Forecast dispersion and the cross section of expected returns. Journal of Finance , 59(5), 1957-1978. http://dx.doi.org/10.1111/j.1540-6261.2004.00688.x

Khurana, I. K., \& P. Michas (2011). Mandatory IFRS adoption and the U.S. home bias. Accounting Horizons, 25(4), 729-753. http://dx.doi.org/10.2308/acch-50075

Kim , J., \& Shi, H. (2012). Voluntary IFRS Adoption, Analyst Coverage, and Information Quality: International Evidence. Journal of International Accounting Research, 11(1), 45-76. http://dx.doi.org/10.2308/jiar-10216

Kim, Y., \& Li, S. (2011). The externality effect of accounting standards convergence: evidence from cross-border information transfers around EU mandatory IFRS adoption. Working paper, Santa Clara University.

King, R., Pownall, G., \& Waymire, B. (1990). Expectations adjustments via timely management forecasts: Review, synthesis, and suggestions for future research. Journal of Accounting Literature, 31(2), 113-144.

Krishnaswami, S., \& Subramaniam, V. (1999). Information Asymmetry, Valuation, and the Corporate Spin-off Decision. Journal of Financial Economics, 53(1), 73-112. http://dx.doi.org/10.1016/S0304-405X(99)00017-3

Kvaal, E., \& Nobes, C. (2010). International differences in IFRS policy choice: a research note. Accounting and Business Research, 40(2), 173-187.

Kvaal, E., \& Nobes, C. (2012). IFRS policy changes and the continuation of national patterns of IFRS practice. European Accounting Review, 21(2), 343-371. http://dx.doi.org/10.1080/09638180.2011.611236

La Porta, R., Lopez-de-Silanes, F., Shleifer, A., \& Vishny, R. (1998). Law and finance. Journal of Political Economy, 106(6), 1113-1155. http://dx.doi.org/10.1086/250042

Landsman, W. R., Maydew, E. L., \& Thornock, J. R. (2012). The information content of annual earnings announcements and mandatory adoption of IFRS. Journal of Accounting and Economics 53(1), 34-54. http://dx.doi.org/10.1016/j.jacceco.2011.04.002

Lang, M., \& Lundholm, R. (1993). Cross-Sectional Determinants of Analyst Ratings of Corporate Disclosures. Journal of Accounting Research, 31(2), 246-271. http://dx.doi.org/10.2307/2491273

Lang, M. H., \& Lundholm, R. J. (1996). Corporate Disclosure Policy and Analyst Behavior. The Accounting Review, 71(4), 467-492.

Lang, M., Maffett, M., \& Owens, E. (2010). Earnings comovement and accounting comparability: the effects of mandatory IFRS adoption. Working paper, UNC-Chapel Hill and University of Rochester.

Leuz, C., Nanda, D., \& Wysocki, P. (2003). Investor protection and earnings management: an international comparison. Journal of Financial Economics , 69(3), 505-527. http://dx.doi.org/10.1016/S0304-405X(03)00121-1

Li, S. (2010). Does mandatory adoption of International Financial Reporting Standards in the European Union reduce the cost of equity capital?. The Accounting Review, 85(2), 607-636. http://dx.doi.org/10.2308/accr.2010.85.2.607

Liang, L. (2003). Post-earnings announcement drift and market participants' information processing biases. Review of Accounting Studies 8: 321-345. http://dx.doi.org/10.1023/A:1024477831740

Liao, Q., Sellhorn, T., \& Skaife, H. A. (2012). The cross-country comparability of IFRS earnings and book values: evidence from France and Germany. Journal of International Accounting Research, 11(1), 155-184. http://dx.doi.org/10.2308/jiar-10215

Márquez-Ramos, L. (2011). European accounting harmonization: consequences of IFRS adoption on trade in goods and foreign direct investments. Emerging Markets Finance and Trade 47(5), 42-57. http://dx.doi.org/10.2753/REE1540-496X4705S403 
Muller, K. A., Riedl, E. J., \& Sellhorn, T. (2011). Mandatory fair value accounting and information asymmetry: evidence from the European real estate Industry. Management Science, 57(6), 1138-1153. http://dx.doi.org/10.1287/mnsc.1110.1339

Nobes, C. W. (1983). A judgemental international classification of financial reporting practices. Journal of Business Finance \& Accounting, 10(1), 1-19. http://dx.doi.org/10.1111/j.1468-5957.1983.tb00409.x

Ormrod, P., \& Taylor, P. (2004). The impact of the change to International Accounting Standards on debt covenants: a UK perspective. Accounting in Europe, 1(1), 71-94. http://dx.doi.org/10.1080/0963818042000262775

Panaretou, A., Shackleton, M. B., \& Taylor, P. A. (2013). Corporate risk management and hedge accounting. Contemporary Accounting Research, 30(1), 116-139. http://dx.doi.org/10.1111/j.1911-3846.2011.01143.x

Preiato, J. P., Brown, P. R., \& Tarca, A. (2013). Mandatory Adoption of IFRS and Analysts' Forecasts: How Much Does Enforcement Matter? (March 21, 2013). UNSW Australian School of Business Research Paper No. 2009 ACCT 01.

Ramnath, S., Rock, S., \& Shane, P. (2008). The financial analyst forecasting literature: A taxonomy with suggestions for further research. International Journal of Forecasting, 24(1), 34-75. http://dx.doi.org/10.1016/j.ijforecast.2007.12.006

Revsine, L., Collins, D. W., \& Johnson, W. B. (2004). Financial Reporting and Analysis, 2nd ed. Upper Saddle River, NJ: Prentice Hall.

Rogers, R., \& Grant, J. (1997). Content analysis of information cited in reports of sell-side financial analysts. Journal of Financial Statement Analysis, 3(1), 17-30.

Schipper, K. (1991). Analysts' Forecasts. Accounting Horizons, 5(4), 105-121.

Schleicher, T., Tahoun, A., \& Walker, M. (2010). IFRS adoption in Europe and investment cash flow sensitivity: outsider versus insider economics. The International Journal of Accounting, 45(2), 143-68. http://dx.doi.org/10.1016/j.intacc.2010.04.007

Sheng, X., \& Thevenot, M. (2012). A new measure of earnings forecast uncertainty. Journal of Accounting and Economics, 53(1), 21-33. http://dx.doi.org/10.1016/j.jacceco.2011.11.001

Shima, K. M., \& Gordon, E. A. (2011). IFRS and the regulatory environment: the case of U.S. investor allocation choice. Journal of Accounting and Public Policy, 30(5), 481-500. http://dx.doi.org/10.1016/j.jaccpubpol.2011.07.001

Soderstrom, N., \& Sun, K. (2007). IFRS Adoption and Accounting Quality: A Review. European Accounting Review, 16(4), 675-702. http://dx.doi.org/10.1080/09638180701706732

Tan, H., Wang, S., \& Welker, M. (2011). Analyst following and forecast accuracy after mandated IFRS adoptions. Journal of Accounting Research, 49(5), 1307-57. http://dx.doi.org/10.1111/j.1475-679X.2011.00422.x

Verriest, A., Gnaeremynck, A., \& Thornton, D. (2013). The impact of Corporate Governance and IFRS adoption choices. European accounting review, 22(1), 39-77. http://dx.doi.org/10.1080/09638180.2011.644699

Wang, C. (2011). Accounting standards harmonization and financial statement comparability: evidence from transnational information transfer. Working paper, University of Pennsylvania.

Wu, J. S., \& Zhang, I. X. (2014). The adoption of internationally recognized accounting standards: implications for the credit markets. Journal of Accounting, Auditing \& Finance 29(2), 95-128. http://dx.doi.org/10.1177/0148558X14524420

Yang, Y. (2011). Three essays on international capital markets. Dissertation. Nanyang Business School.

Yeung, P. (2009). Uncertainty and expectation revisions after earnings announcements. Contemporary Accounting Research, 26(1), 273-301. http://dx.doi.org/10.1506/car.26.1.10

Yu, G. (2010). Accounting standards and international portfolio holdings: Analysis of cross-border holdings following mandatory adoption of IFRS. Dissertation, University of Michigan.

Zeff, S. (2007). Some obstacles to global financial reporting comparability and convergence at a high level of quality. British Accounting Review, 39(4), 290-302. http://dx.doi.org/10.1016/j.bar.2007.08.001 